\title{
The Cartography of National Humiliation and the Emergence of China's Geobody
}

\author{
William A. Callahan
}

Like a debutante on the world stage, China has been modeling national images for its ongoing coming-out party. After decades of revolutionary diplomacy that challenged the international system, since the 1990s the People's Republic of China (PRC) has worked hard to ease the concerns of countries that used to be targets of its revolutionary activities. China as a "peacefully rising" great power that aims to create a "harmonious world" is Beijing's latest narrative that seeks to present the PRC to the world as a cuddly panda rather than a ravenous dragon.

Maps are an important part of the continual self-crafting of any nation's image. As the Chinese maps examined here will show, the very material borders between foreign and domestic space are the outgrowth of the symbolic workings of historical geography and the conventions of Chinese cartography. These maps do much more than celebrate the extent of Chinese sovereignty; they also mourn the loss of national territories through a cartography of national humiliation. In this way, the messy geopolitics of disputed borders is informed by the contingent biopolitics of identity practices.

I would like to thank the many people who helped me find maps at the National Library of China, the Library of Congress, the British Library, the Academia Sinica (Taiwan), Harvard University, Cornell University, the Chinese University of Hong Kong, and the Hoover Institution Archives. For their help and critical comments, I thank Manjari Chatterjee Miller, Richard J. Smith, Michael J. Shapiro, Gordon C. K. Cheung, Daniel Bertrand Monk, Sumalee Bumroongsook, David Kerr, Kirk W. Larsen, Robert J. Kibbee, and Min Zhang. This research was funded with grants from the centers for Chinese studies at Durham and Manchester Universities, the British Academy, and the Woodrow Wilson International Center for Scholars. Unless otherwise noted, all translations from Chinese are my own.

Public Culture 21:1 Dol 10.1215/08992363-2008-024 


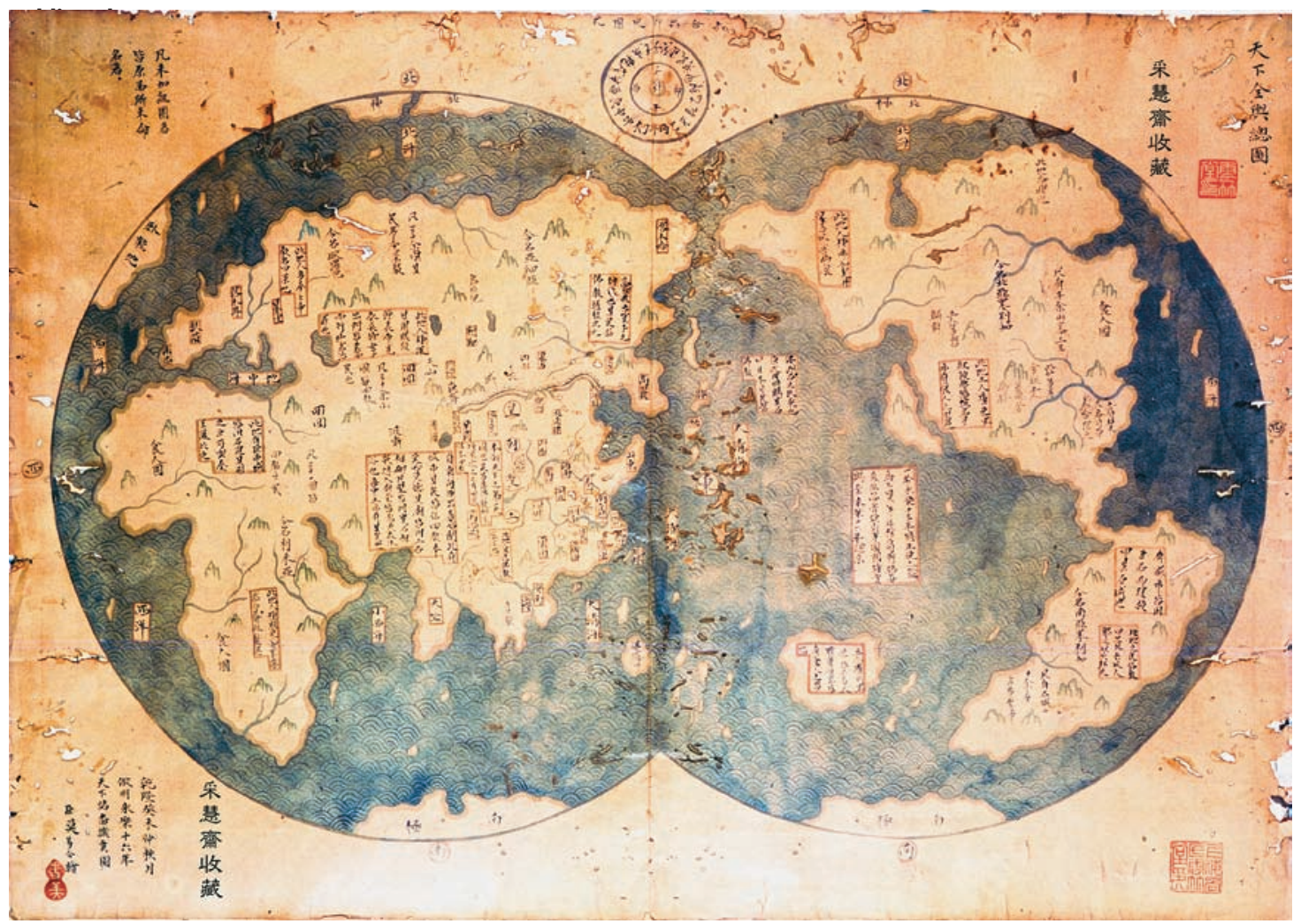

Figure 1 Zheng He's American voyage (1418). www.1421.tv/assets/ images/maps/1418_map _download.jpg
The maps in figures 1 and 2 give a sense of the complexities of China's engagement with the world. The map in figure 1 is evidence of China as a confident world power that has global influence. It charts the Ming dynasty voyages of Admiral Zheng He from China to (what we now call) Southeast Asia and the Indian Ocean, eventually reaching Africa's east coast. What is noteworthy about this particular map from 1418, which was discovered by a Chinese collector in 2001, is that it also charts Zheng's voyages to the East, suggesting that the admiral "discovered" America before Columbus. ${ }^{1}$ And as we know, "discovering America" is part of the symbolic politics of being a great power. ${ }^{2}$

1. "Chinese Cartography: China Beat Columbus to It, Perhaps," Economist, January 12, 2006, www.economist.com/displaystory.cfm?story_id=5381851. Gavin Menzies has adopted this map, which he calls the "1418 Map," and posted it on his "1421: The Year When China Discovered the World” Web site, www.1421.tv/assets/images/maps/1418_map_download.jpg (accessed January 15, 2008).

2. Walter D. Mignolo, The Darker Side of the Renaissance: Literacy, Territoriality, and Colonization (Ann Arbor: University of Michigan Press, 1995), 219-313. 


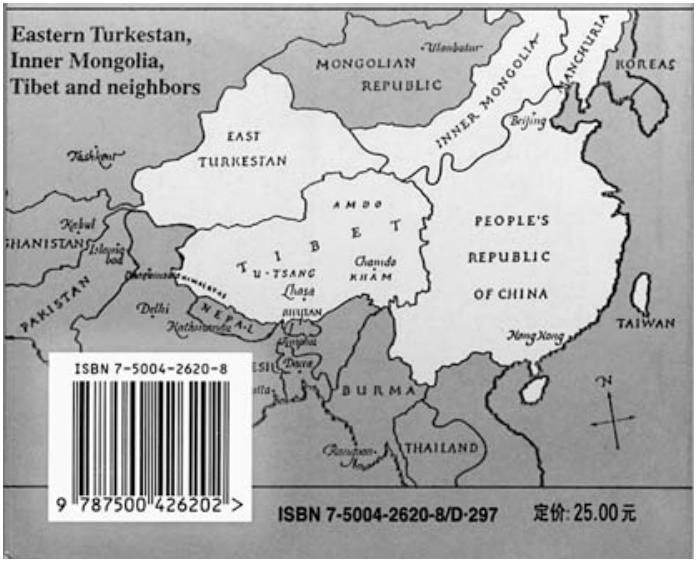

Figure 2 Back cover of China's Road (1999). Wang, Fang, and Song, Quanqiuhua yinxiang xiade Zhongguo zhi lü
Cartography of National Humiliation

If figure 1's map asserts a confident outward-looking China, then figure 2's map represents China's fears of national disintegration. This map, which was published on the cover of the best-selling hypernationalist book China's Road under the Shadow of Globalization (1999), presents China as the victim of an international conspiracy to divide up the PRC into a clutch of independent states including Tibet, Manchuria, Inner Mongolia, East Turkestan, and Taiwan. ${ }^{3}$ The authors tell us that this is a popular map in the West and have the "original" English-language version of this unraveling of China on the back cover, with a Chinese translation on the front cover. This map thus is taken as evidence of Western plans to keep the PRC from achieving its rightful status as a major power on the world stage.

Although both maps assert their authenticity as evidence of either Chinese discovery or Western conspiracy, it turns out that neither map is authentic in the sense of representing what it purports to represent. Because it is full of anachronisms and has an unclear provenance, there are serious doubts about the authenticity of the world discovery map — most people now see it as a hoax. ${ }^{4}$ Although the authors of China's Road say that it is a popular map in the West, no one has been able to track down its source. ${ }^{5}$

3. Wang Xiaodong, Fang Ning, and Song Qiang, Quanqiuhua yinxiang xiade Zhongguo zhi lü (China's Road under the Shadow of Globalization) (Beijing: Shehui Kexue Chubanshe, 1999).

4. See, e.g., Joseph Kahn, "Storm over 1418 Map: History or Scam?" International Herald Tribune, January 17, 2006, www.iht.com/articles/2006/01/16/news/map.php. Menzies's argument that China discovered America in 1421 is also seen as a hoax by most historians. Gavin Menzies, 1421: The Year When China Discovered the World (New York: Perennial, 2003).

5. See Roger Des Forges and Luo Xu, "China as a Non-hegemonic Superpower? The Uses of History among the China Can Say No Writers and Their Critics," Critical Asian Studies 33 (2001): 498, 507. 
Yet a search for "authenticity" misses the point of such maps: they are not reflecting reality so much as asserting a normative image of China. These two maps are aspirational, first in the positive sense of presenting China as a united and great power with global influence, and second in the negative sense of what China does not want to be: "carved up like a melon," to use a popular Chinese phrase from the early twentieth century. Indeed, this is not strange; even many official Chinese maps are actually imaginative and aspirational, inscribing territories that are not under state control — but could and should be part of China's sovereign territory: PRC maps record Taiwan as a province of China, and until recently Republic of China (ROC) maps included Outer Mongolia as well. This illustrates how national maps are not simply scientific reflections of the territory of the "real world"; maps are technologies of power used for political projects. Chinese atlases from the early twentieth century, for example, characteristically state that the new Republic (founded in 1912) needed national maps to know just what it was ruling. ${ }^{6}$ The title of a recent academic article describes the enduring goal of Chinese cartography: "A Century of Anticipating the Unification of the Motherland."'

Here I follow those who treat maps and cartography as political practices that seek to produce what Thongchai Winichakul calls the national "geobody," which is "not merely space or territory. It is a component of the life of a nation. It is a source of pride, loyalty, love, . . hatred, reason, [and] unreason."8 As massproduced visual artifacts, maps are more than scientific representations of "reality"; they constitute a symbolic discourse that can mobilize the masses. In this way, maps not only tell us about the geopolitics of international borders; when they inscribe space as a geobody, maps also tell us about the biopolitics of national identity practices.

Maps and cartography thus are deployed in the dynamic of cultural governance and resistance in China and Asia. In this sense, the region is not unique; it is participating in the process of capitalist modernity, where the state seeks to match territorial and cultural boundaries not only through military coercion and fiscal regulation but also through a management of identity practices. Since the

6. See, e.g., Chen Gaoji, preface to Zhongguo xin yutu (New Atlas of China) (Shanghai: Commercial Press, 1925).

7. Zhao Dachuan, "Shiji qipan zuguo tongyi" ("A Century of Anticipating the Unification of the Motherland"), Ditu (Cartography), no. 2 (2000): 39-44.

8. Thongchai Winichakul, Siam Mapped: A History of the Geo-body of a Nation (Honolulu: University of Hawaii Press, 1994), 17. See also Benedict Anderson, Imagined Communities: Reflections on the Origin and Spread of Nationalism, rev. ed. (New York: Verso, 2006), 170-78. 
state can never exhaust cultural production, resistance to these centralizing efforts takes the form of alternative cultural productions, including alternative maps that inscribe various alternative geobodies. ${ }^{9}$

In this sense, producing and regulating the geobody is a technique of "biopower," which, as Michel Foucault explained, expanded the notion of politics from juridical concepts of power that restrict action under the threat of death to a productive understanding of power that emphasizes the fostering of life. ${ }^{10}$ Biopolitics is especially useful for understanding the emergence of a national body politic in China because the country was known as the "Sick Man of Asia," whose life needed to be saved (jiuguo). As we will see, re-membering territories that had been dismembered (fenge) is a key way of imagining — and then managing China's geobody in a way that combines biopolitics and geopolitics.

Hence the borders of the Chinese geobody are neither obvious nor fixed; they are contingent on historical events and are framed by cartographic conventions. China's borders are the product of debate and struggle as the country has gone through major transitions first from an empire to a nation-state in the early twentieth century, and now from an isolated revisionist state to an engaged superpower at the turn of the twenty-first century. Hence the struggle about the proper size and shape of China is not only with foreign countries along frontier zones but within China in debates among different groups, which each draw different "national maps" to support their preferred geobodies. While it is popular to analyze Euro-American images of China to critique Western orientalism, this essay is more concerned with the identity politics of Chinese images of its own region, which as we will see grow out of the collision of imperial Chinese cartography and modern scientific maps.

Thus, rather than just trace the geopolitics of how the shape of China has changed in its encounter with modernity, the maps discussed in this essay raise a set of conceptual issues. To understand the Chinese geobody, we need to engage in comparative cartography - but rather than compare East and West, we need to consider China's uneasy shift from premodern unbounded understandings of space and territory to bounded understandings of space and territory in the early twentieth century. Simply put, I question the common argument that there

9. See Michael J. Shapiro, Methods and Nations: Cultural Governance and the Indigenous Subject (New York: Routledge, 2004), 49; and William A. Callahan, Cultural Governance and Resistance in Pacific Asia (London: Routledge, 2006), 1-20.

10. See Michel Foucault, The History of Sexuality: An Introduction (New York: Vintage, 1990), 133; and Foucault, "Society Must Be Defended": Lectures at the Collège de France, 1975-1976 (New York: Picador, 2003). 
has been a shift from the late imperial Chinese concept of unbounded domain (jiangyu) to a modern understanding of bounded sovereign territory (zhuquan lingtu). ${ }^{11}$ The maps will show how imperial domain and sovereign territory both still work — often in creative tension — to inscribe the PRC's twenty-first-century geobody on the Chinese imagination.

This creative tension is manifest in a set of Maps of China's National Humiliation, which as I argue form a link between imperial China's unbounded cartography and its modern maps of sovereign territory. These national humiliation maps help us understand the emergence of China's geobody because they are produced for mass education to chart how China "lost territories" to imperialist aggressors as it was dragged into modernity starting with the Opium War in $1840 .{ }^{12}$ Yet these national maps do more than publicly register China's aspirational claims to various neighboring territories. I argue that these normative national maps actually tell us more about the fragile biopolitics of China's new identity as a great power than about the geopolitics of Asian security.

To understand how China's geobody emerges at the confluence of unbounded imperial domain and modern sovereign territory, it is helpful to see how Thailand used three discursive strategies to claim many of its vassals as sovereign national territory. ${ }^{13}$ The first strategy for claiming imperial possessions as national territory is to deny the difference between imperial domain's hierarchical unbounded space and sovereign territory's homogeneous bounded space. The second strategy is to establish the stories of China's sovereign territoriality in the context of modern international politics — particularly colonialism — as opposed to China's own history of imperial conquest. The third strategy is to read territoriality exclusively from Beijing's point of view, and thus suppress any rival perspectives - from Lhasa, Kashgar, or Taibei - that might dispute the scope of China's normative geobody. As we will see, Chinese cartography employs these three discursive strategies to essentialize the Qing dynasty's imperial domain into the PRC's national sovereign territory.

11. Lü Yiran, ed., Zhongguo jindai bianjie shi (History of China's Modern Borders), 2 vols. (Chengdu: Sichuan Renmin Chubanshe, 2007), 1:1-2; for a more critical view, see Huang Donglan, "Lingtu, jiangyu, guochi: Qingmo Minguo dili jiaokeshu de kongjian biaoxiang" ("Territory, Domain, and National Humiliation: Concepts of Space in Geography Textbooks from the Late Qing and Republican Periods"), in Shenti, xinxing, quanli (Body, Mind, and Power), ed. Huang Donglan (Hangzhou: Zhejiang People's Press, 2005), 77-79.

12. For a critical analysis of how "the century of national humiliation" informs modern identity practices in China, see William A. Callahan, "National Insecurities: Humiliation, Salvation, and Chinese Nationalism," Alternatives 29 (2004): 199-218.

13. This argument is summarized from Thongchai, Siam Mapped, 147-48. 
This essay has two general aims: (1) to demonstrate how China's current national maps have emerged through the creative tension of unbounded imperial domain and bounded sovereign territory, and (2) to show how the cartography of national humiliation informs the biopolitics of the geobody. The goal of the essay thus is not to determine China's correct boundaries in legal discourse or geopolitical space. Rather, it seeks to examine what Chinese maps of China can tell us about their hopes and fears, not only in the past or present but also for the future. The analysis therefore is not limited to the standard questions of political geography and border disputes; it examines the biopolitics of how China's image of itself interacts with its image of the world. As I suggest later in the conclusion, China's often unique experience can show us how cartography is an important site of struggle in a broader biopolitics of geobodies.

\section{Comparative Cartography 1: Imperial Domain and Sovereign Territory}

Normative maps certainly are not exclusive to China. Mappamundi in late medieval Europe also represented normative space: not how the world was but how it should be. The map "Europe as a Virgin" (1592), for example, presents a literal geobody of Europe with the Iberian Peninsula as the queen's head and Denmark and Italy as her arms, with a medallion over her heart in Bohemia where the map was produced. ${ }^{14}$ Starting in the sixteenth century, Europe used more scientific maps both to conquer the world and to create the world map to divide up the globe into sovereign territories divided by clear boundaries. Thus Walter D. Mignolo argues that the symbolic politics of drawing maps to claim imperial space and sovereignty was a key part of conquering the world, because this new cartography "coloniz[ed] the imagination" of both the conquered and the conquerors. ${ }^{15}$

To understand the interplay of imperial domain and sovereign territory on twentieth-century Chinese maps, we need to consider late imperial Chinese cartography. Figure 3's "Untitled Map" (1743) presents a good example of one of the key genres of imperial Chinese cartography; it reflects the style of a "Huayi tu" - a map of civilization and barbarism. ${ }^{16}$ If we look closely at this large and complex map, we can see that the borders are not between territories so much as

14. Johannes Putsch, La vergine Europa (Europe as a Virgin) (1592).

15. Mignolo, Darker Side, 218. See also J. B. Harley, "Deconstructing the Map," Cartographica 26 (1989): 1-20; and Gearóid Ó Tuathail, Critical Geopolitics (Minneapolis: University of Minnesota Press, 1996), 1-20.

16. "Untitled Map" (1743), British Library. The most famous "Huayi tu" (1136) is inscribed on a stone stele now housed in Xi'an, China. A rubbing of this map is available at the Library of Congress. 
Public Culture

Public Culture

Figure 3 Civilization and

barbarism (1743). British

Library Board, shelfmark

15406.a.28

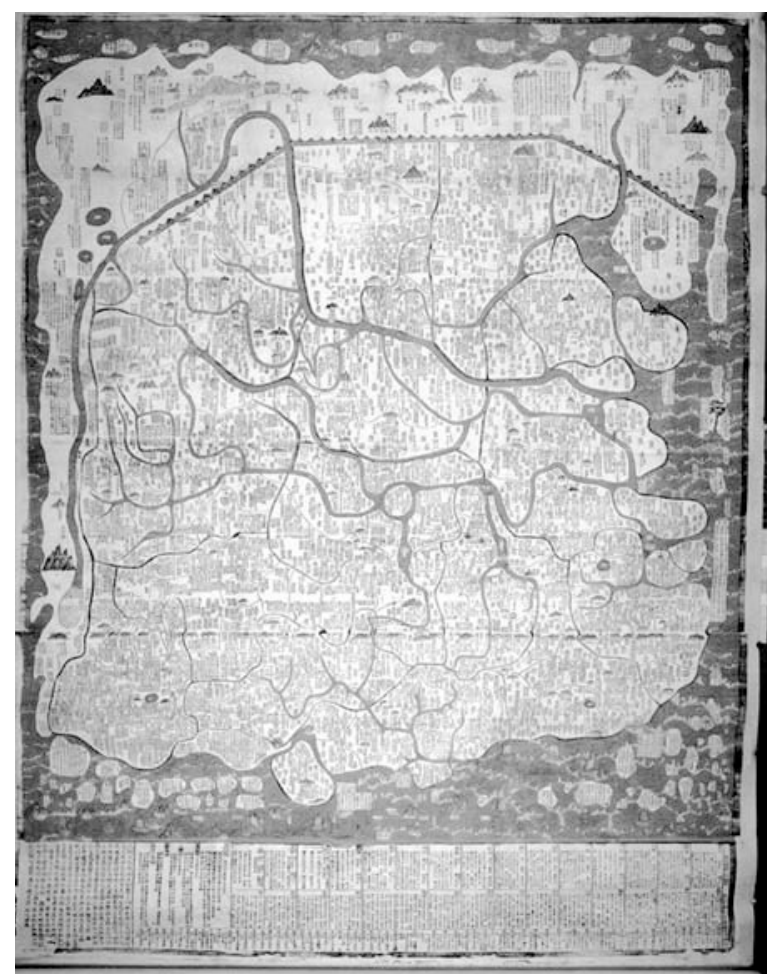

between peoples and cultures: civilization and barbarians. This genre of imperial map presents China at the center of the world, and often as the world itself. On such maps, foreign countries - even Vietnam and India, let alone Portugal, England, and America - appear as small and insignificant islands off China's coast.

It is difficult to read late imperial maps if you do not know the conventions of Chinese cartography — which suggests that reading modern mathematical maps is not natural, either, but depends on unspoken conventions. ${ }^{17}$ Simply put, the

17. For a critical discussion of the conventions of premodern Chinese maps, see the chapters by Cordell Yee in Cartography in the Traditional East and Southeast Asian Societies, vol. 2, bk. 2, of The History of Cartography, ed. J. B. Harley and David Woodward (Chicago: University of Chicago Press, 1994), 35-230; Richard J. Smith, Chinese Maps: Images of "All under Heaven" (Oxford: Oxford University Press, 1996); Smith, "Mapping China's World: Cultural Cartography in Late Imperial Times," in Landscape, Culture, and Power in Chinese Society, ed. Wen-hin Yeh (Berkeley: University of California, Institute of East Asian Studies, 1998), 52-105; and Peter C. Perdue, "Boundaries, Maps, and Movement: Chinese, Russian, and Mongolian Empires in Early Modern Central Eurasia,” International History Review 20 (1998): 263-86. 
main convention of imperial Chinese maps is hierarchy. Such maps represent not a homogeneous space of equal sovereignty and legitimacy but a hierarchy of concentric circles with diminishing sovereignty as one travels from the imperial capital out to the periphery of provinces, vassal states, and finally the barbarian wilderness. The result of this style of cartography is that imperial maps of China's domain are very detailed at the center but very vague at the margins. Rather than the single line boundaries that define the sovereign territories of the Westphalian international system, imperial Chinese cartography often mapped an ambiguous and unbounded domain of empty or overlapping frontiers.

While normative maps are a curiosity in Euro-American cartography, they have enduring value in China: the first truly modern map of China based on scientific surveys was published for public consumption in $1934 .{ }^{18}$ Hence any clear division between late imperial aesthetic maps and modern scientific maps is misleading; China presents a case where normative mappamundi of imperial domains inform and overlap with scientific cartographs of sovereign territory. Chinese cartography thus inscribes a coalescence of the two distinct worlds of cosmography and geography; China's twentieth-century maps exemplify the simultaneous appeal to two quite different readings of space: the ambiguous frontiers of the imperial domain and the clear national boundaries of the international system. ${ }^{19}$

To chart the emergence of China's geobody, I analyze a set of Maps of China's National Humiliation that first were published in China between the founding of the ROC in 1912 and Japan's all-out invasion of China in 1937, which then reappeared after the Tian'anmen movement (1989) as part of the PRC's patriotic education campaign. These national humiliation maps are important for three reasons. First, they graphically show the tension between the two ways of mapping China outlined above; they thus provide a colorful link between the cartographies of imperial domain and sovereign territory. Second, they are very deliberately published as part of patriotic education campaigns for public edification. In the Republican period these large wall maps of national humiliation were an important part of the emergence of nationalist geography education in China; they were published by government bodies, geographic societies, and commercial

18. Iwo Amelung, "New Maps for the Modernizing State: Western Cartographic Knowledge and Its Application in Nineteenth and Twentieth Century China," in Graphic and Text in the Production of Technical Knowledge in China: The Warp and the Weft, ed. Francesca Bray, Vera DorofeevaLichtmann, and Georges Métailié (Leiden: Brill, 2007), 34; Ding Wenjiang, Weng Wenjing, and Zeng Shiying, Zhonghua minguo xin ditu (New Map of the Republic of China) (Shanghai: Shenbao Guan, 1934).

19. Mignolo, Darker Side, 253-54; Huang, "Lingtu, jiangyu, guochi." 
presses for classroom use and public consumption alongside mainstream national maps. National humiliation maps published at the turn of the twenty-first century are likewise very public artifacts that are part of the PRC's multimedia patriotic education campaign.

Third, national humiliation maps not only make expansive and aspirational claims to huge tracts of land as China's national territory; they also address the enduring Chinese anxiety of falling apart seen in figure 2. Indeed, many have noted that an obsession with unity is not simply a modern concern that arose in reaction to China's tragic modern history, which is seen as a history of European, American, and Japanese imperialist aggression. While Euro-American philosophy asserts a solid objective reality that needs to be deconstructed, "in the Chinese case, in contrast, it is of a dispersed reality, in the face of which a reconstructive need has often struggled." 20 Similar national humiliation maps from the turn of the twenty-first century suggest that this search for "great unity" (da yitong) not only is part of China's enduring political culture but continues to be one of the main theoretical frameworks for historical geography in the PRC. ${ }^{21}$

To see how the three discursive strategies of the cartography of national humiliation crafted China's geobody, we need to look at how the interplay of positive and negative images actually constructed the map of China that is familiar today.

\section{Defining China's Borders 1: Outside/In}

To understand how the geobody emerged through an interplay of imperial domain and sovereign territory, it is helpful to see how on Chinese maps the outside defines the inside, and the inside defines the outside. The first official map of the ROC, which was published in the Republic's founding Almanac (1912), graphically shows the ambiguity of China's borders (see fig. 4). This Almanac is interesting precisely because it does not simply list dates and places. The Almanac actively asserts a new time for a new China by instituting a new calendar, complete with tables to convert dates from the old imperial lunar calendar to the new Republican Julian calendar. Likewise, the Almanac's "Map of the Republic of China" carves out a new space for this nascent nation-state; as with the new calendar, the new map was "issued for enforcement." 22

20. John Hay, "The Body Invisible in Chinese Art?" in Body, Subject, and Power in China, ed. Angela Zito and Tani E. Barlow (Chicago: University of Chicago Press, 1994), 52.

21. Anonymous historical geographer, interview by author, Beijing, July 16, 2007.

22. Zhonghua mingguo yuannian lishu (Almanac of the First Year of the Republic of China) (Hunan Yanshuo Zongke Yin, 1912). 


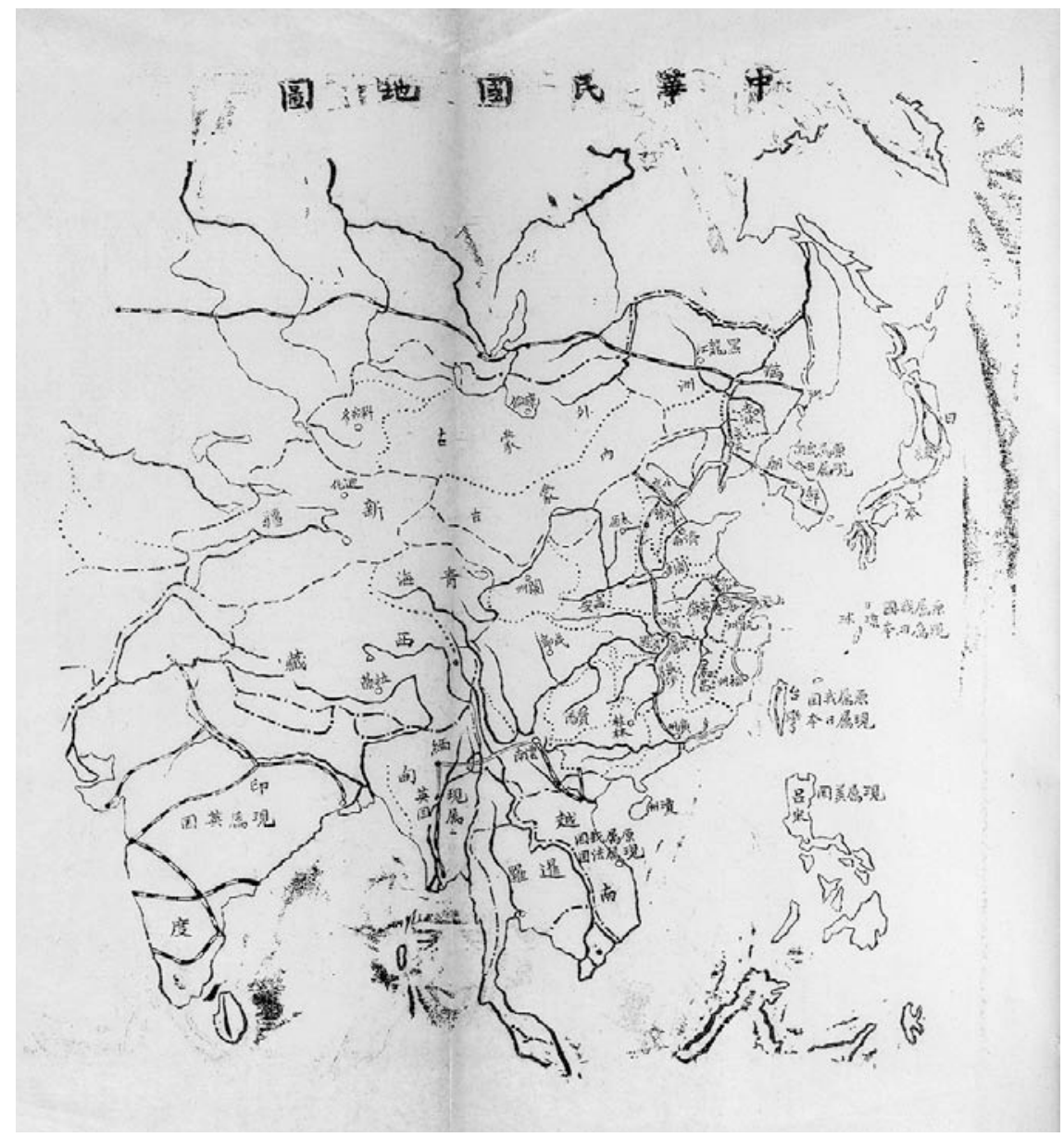

Figure 4 The Republic of China (1912). British Library Board, shelfmark 15298.a.66

Still, this map of China and its Asian neighbors does not assert clear boundaries between the ROC and other sovereign states; it is actually hard to pick "China" out from the rest of the continent. The map is thus like the first constitutions of the ROC, which state that "the sovereign territory of the Republic of China continues to be the same as the domain of the former Empire." ${ }^{23}$ But this simply begs the

23. The Constitutional Compact of the Chung Hua Min Kuo, bilingual ed., Peking Daily News, May 1, 1914, chap. 1, article 3. The ROC's 1923 Constitution obscures this transition by axiomatically declaring that "the territory which originally belonged to the Republic shall be the territory of 
question of defining the domain of the Qing dynasty — which, as we saw above, relied on a different way of mapping the world. While maps of the late Qing empire are characteristically dotted with textual annotations, the Republican map is largely blank. ${ }^{24}$ On this 1912 national map, physical and economic geographies are more important than political geography: the lines marking rivers and railroads are more prominent than those defining international boundaries. The first official map of China thus shows that in the early twentieth century it was not clear how the Qing imperial domain would map onto the sovereign territory of the new Republic: if we look closely, we can see that this map is already claiming much of Central, East, and Southeast Asia as lost territory for the Republic. While the Qing dynasty's late imperial maps marked various places as vassals, the Almanac's map of the Republic marks Korea, Vietnam, and other territories as "originally our vassal, now a vassal of Japan/France/Britain." As on the "Untitled Map" of civilization and barbarism (1743), China is Asia. China's first national map thus reproduces the logic of imperial cartography to frame neighboring territories as part of China's domain.

The "Map of Chinese National Humiliation" (1916, fig. 5) and the "Map of China's National Humiliation" (1930, fig. 6) graphically demonstrate both the anxiety of China unraveling and the importance of asserting a new unity through the Republic. ${ }^{25}$ But these maps link imperial domain and sovereign territory in an interesting and unexpected way. Rather than focus on China's geopolitical torso and show how various territories have been carved off, it does the opposite to stress how the outside defines the inside. In ways similar to the Almanac map (1912), China is portrayed as empty, blank, and white, while "lost territories" are inscribed in living color: bright red shading on the 1916 map and yellow and pink coloring on the 1930 version. ${ }^{26}$ These maps thus highlight China's boundaries in

the Republic of China" (Constitution of the Republic of China [Peking: Commission on Extraterritoriality, 1924], chap. 3, article 3).

24. In addition to the "Untitled Map" (1743), see "Da Qing wannian yitong dili quantu" ("Complete Universal Map of the Unified Great Qing Empire") (1816). An image of this map is posted on the Library of Congress Web page hdl.loc.gov/loc.gmd/g7820.ct002256 (accessed November 10, 2008)

25. "Zhonghua guochi ditu" ("Map of Chinese National Humiliation") (Shanghai: Central Cartographic Society, 1916); "Zhongguo guochi ditu" ("Map of China's National Humiliation”), in Zuixin Zhonghua minguo gaizao quantu (The Atlas of the Republic of China, with the Latest Corrections), comp. Bai Meichu (Beiping: Jianshe Tushuguan, 1930), map 2.

26. For other examples of a white and blank China surrounded by "lost territories" marked with red slashes, see "Zhonghua guochi ditu" ("Map of Chinese National Humiliation") (Henan Provincial Government, 1922); "Zhonghua guochi ditu" ("Map of Chinese National Humiliation") (Industry 


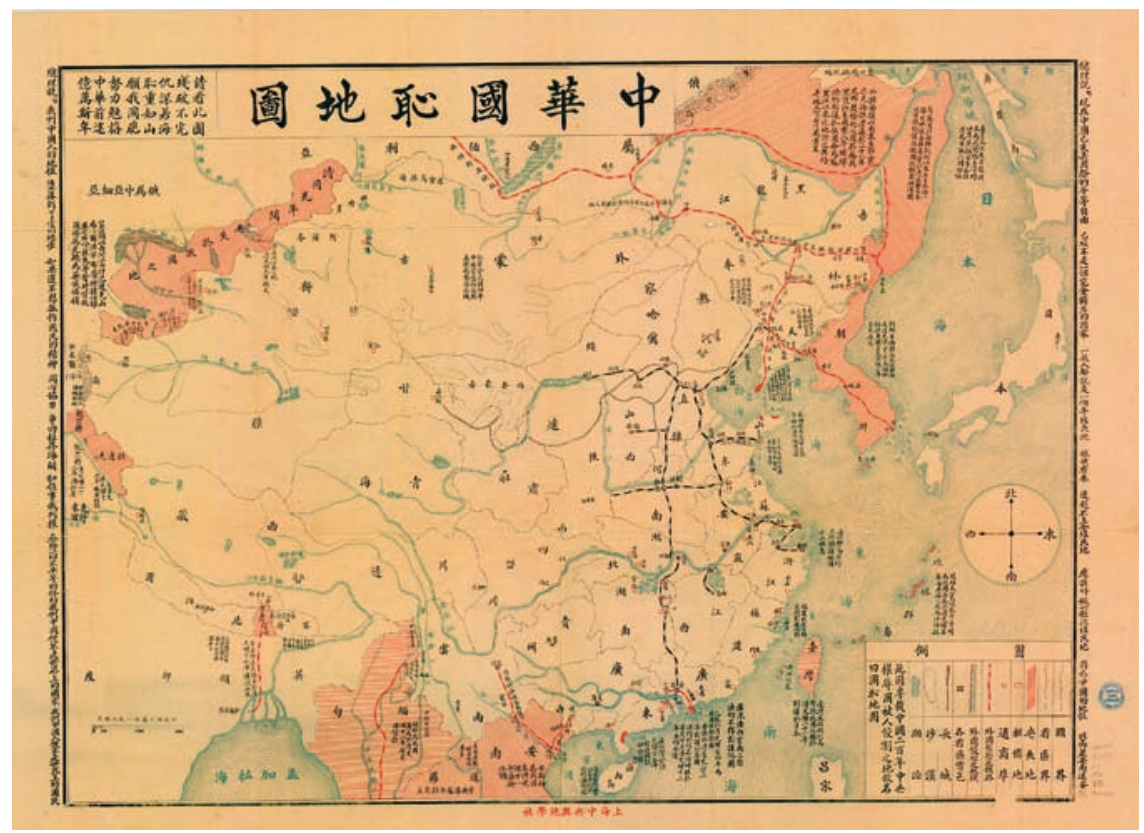

Figure 5 "Map of Chinese National Humiliation" (1916). Courtesy of Cornell University Library

an odd way. Identity and territoriality are negative: the maps tell you what you do not want to be, rather than what you want to be.

Importantly, these maps of national humiliation each chart a different set of "lost territories." Instead of using mathematical surveys to clarify China's territorial boundaries, they appeal to the contingencies of historical geography. Rather than China's borders settling down as the ROC adjusted to being a nation-state among other nation-states in its first few decades, its geobody was actually very unstable. As the differences in the 1916 and 1930 maps show, there was no obvious agreement of just which territories were "lost." Other maps confirm that the territorial claims of China's national humiliation maps actually were expanding in the 1920 s and 1930 s. ${ }^{27}$

and Commerce Association of Hebei Province, 1929); and "Aiguo ditu: Guochi yu guochan yilan" ("Patriotic Map: National Humiliation and National Assets in One View") (Meeting of the Central Government, Wuhan Branch meeting, 1929).

27. Huang uses geography textbooks to make the same argument about an expanding popular view of "lost territories" in early-twentieth-century China ("Lingtu, jiangyu, guochi," 90). 


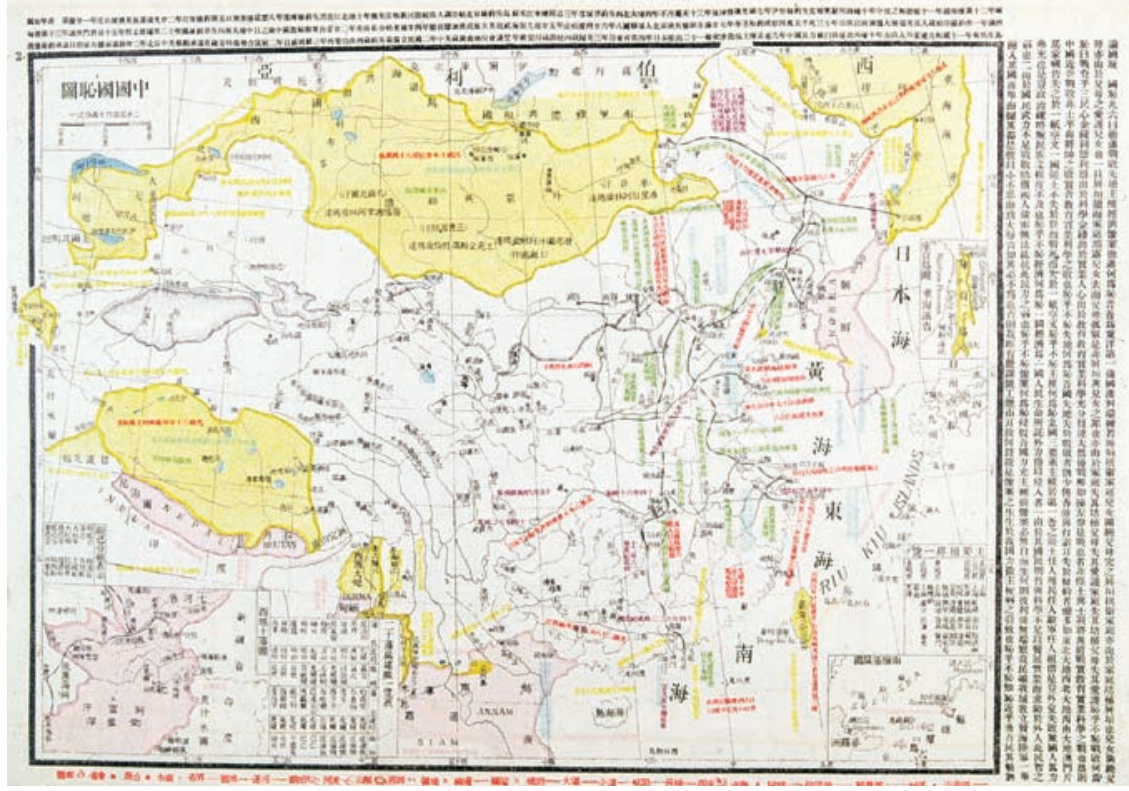

Figure 6 "Map of China's National Humiliation" (1930). Bai, Zuixin Zhonghua minguo gaizao quantu

In a technical sense, these maps invert the hierarchical logic of China's imperial maps of civilization and barbarism. The imagination shifts here from the center to the periphery: the outside defines the inside, and bleeding wounds define the geobody. The trauma of national humiliation generates a national community by setting its normative and aspirational boundaries. These semiofficial maps are important because they were produced for popular consumption and mass education. As the cartographer of the "Map of China's National Humiliation" (1930) explains, the aim is "to make beautiful maps with simple explanations . . . that are fun for the youth . . . and help common people to be patriotic."28

\section{Defining China's Borders 2: Inside/Out}

Another set of modern Republican maps reproduces the logic of imperial maps in a more direct and obvious inside/out way. The "Map of China's National Humiliation" (1927, fig. 7) reasserts the imperial cartography of hierarchical concentric

28. Bai, preface to Zuixin Zhonghua minguo gaizao quantu, 1. 


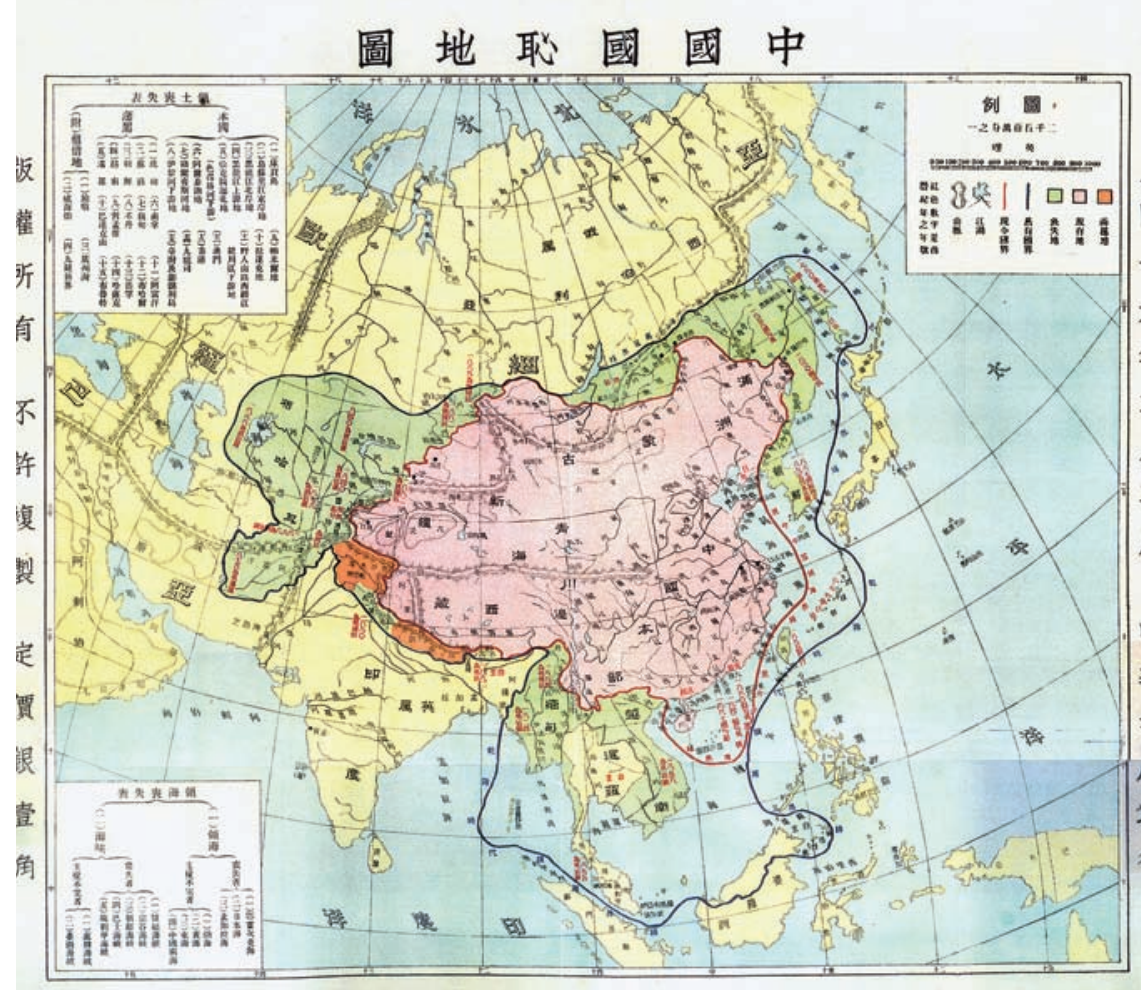

Figure 7 "Map of China's National Humiliation" (1927). Chinese University of Hong Kong

circles on a modern map. ${ }^{29}$ It is important to note that the outer ring, which claims an extraordinarily expansive imperial domain as China's sovereign national territory, is labeled the "old national boundary" — not the old boundary of the Qing empire. Compared with the maps in figures 5 and 6, this "Map of China's National Humiliation" claims an even larger domain as Chinese national territory. As on other "inside/out" national humiliation maps, a graphic display of "lost territories" is complemented by a textual list of "lost territories" in an inset box. ${ }^{30}$ The 1927 map lists fifteen lost "homeland territories," fifteen lost "vassals,"

29. "Zhonghua guochi ditu, zaiban" ("Map of China's National Humiliation, Reprint”) (Shanghai: Zhonghua Shuju, 1927).

30. For similar maps of concentric circles and "lost territories," see "Zhongguo jianming guochi yutu" ("Simple Map of China's National Humiliation") (Jiangsu Army Surveying Department, 
four "territorial concessions," and another fourteen lost and disputed "maritime territories."

Some of these "lost territories" now seem obviously "Chinese": Hong Kong, Macao, and Taiwan were ceded in treaties to the British, Portuguese, and Japanese empires. But other "lost territories" are not so obviously Chinese possessions: the map claims most of the countries in what we now call Southeast Asia and Central Eurasia, as well as Korea and the Russian Far East in Northeast Asia and the Himalayan states of South Asia. Moreover, all the national humiliation maps dot China's geobody with notes (often in red ink) that mark treaty ports, massacres, and other wounds to the geobody from the era of imperialist aggression. The Geography of China's National Humiliation (1930) textbook makes the political purpose of such illustrations and annotations clear; it states that since China has lost more than half its territory, it is necessary to "compile a geographical record of the rise and fall of our country in order to craft a government policy to save it." 31

This set of national humiliation maps of "lost territories" thus seeks to combine the expansive cosmology of late imperial maps with the scientific geography of maps of China's sovereign territory. Through the logic of outside/in and inside/ out, China's early-twentieth-century cartography asserted the true and proper shape of the Chinese geobody as a hybrid of late imperial and modern notions of space.

\section{Defining China's Borders 3: Post-Tian'anmen Maps}

With the eruption of World War II in Asia in 1937, the normative cartography of national humiliation was displaced by the massive national crisis of the Japanese invasion of China proper, which eventually led to the Communist revolution in 1949. Although maps of "lost territories" continued to be published in history and geography textbooks, the PRC's new national and historical maps generally followed a different path, to highlight the more affirmative ideological politics of class struggle and revolutionary victory. ${ }^{32}$ This is what makes the reemergence of

1928); "Zhongguo guochi ditu" ("Map of China's National Humiliation"), in Gu Yijun, Zhongguo guochi dilixue (Geography of China's National Humiliation) (Beiping: Wenhua Xueshe Yinxing, 1930); and "Zhongguo sangshi lingtu linghai tu" ("Map of China's Lost Land and Maritime Territories"), in Xie Bin, Zhongguo sangdi shi (The History of China's Lost Territories) (Shanghai: Zhonghua Shuju, 1925).

31. Gu, Zhongguo guochi dilixue, 1.

32. Historical atlases published in Taiwan after 1949 also often take for granted the logic of "imperial domain" and "lost territories." See the middle school geography textbook Zhongguo lidai 
national humiliation maps in the PRC after a fifty-year hiatus remarkable: they became popular again in China's modern history textbooks in the 1990s as part of a wider policy of national humiliation education, which is part of patriotic education policy. As I have argued elsewhere, national humiliation discourse reemerged after the June 4 massacre as part of the Chinese Communist Party's multimedia campaign, which aimed to refocus the Chinese youths' critical ire on foreign enemies rather than on the internal corruption of the party-state. ${ }^{33}$

The best example of recent national humiliation maps is the book Maps of the Century of National Humiliation of Modern China (1997), which contains eighty-six pages of maps, pictures, charts, illustrations, and explanations. ${ }^{34}$ It shares many themes with similar maps from the early twentieth century. The way China's territories were lost to Russia, for example, is recorded on the "Map of Czarist Russia's Occupation of China's Sovereign Territory" much as it is on the "Map of Chinese National Humiliation" (1916) — down to the details of the different styles and colors of shading to mark territories lost at different times (see figs. 8 and 5). ${ }^{35}$

But the 1997 atlas of national humiliation raises the stakes, because it argues its case much more forcefully and in much greater detail than earlier wall maps. While national humiliation maps from the early twentieth century were published by geographic societies, provincial governments, and commercial presses, the 1997 atlas of national humiliation was edited by the Cartographic Department of China's official People's Press and was distributed as a mass-market publication through the official network of New China Bookstores. Moreover, the book launch of this official publication was a major media event timed to mark the return to Chinese sovereignty of a key lost territory: Hong Kong. Interestingly, the tone of Maps of the Century of National Humiliation does not follow the official slogans to "celebrate the return of Hong Kong to the bosom of the motherland." Rather, the cartographic agony of the early twentieth century is republished as a new anxiety about China's geobody in 1997.

jiangyu xingshi shitu (Historical Atlas of China's Historical Domain) (Taibei: Zhongguo Shengming Xian Zazhi She Yinxing, 1964), 50-55, 60-67. Many thanks to Richard Curt Kraus for sharing this book with me.

33. See William A. Callahan, "History, Identity, and Security: Producing and Consuming Nationalism in China," Critical Asian Studies 38 (2006): 185-87.

34. Jindai Zhongguo bainian guochi ditu (Maps of the Century of National Humiliation of Modern China) (Beijing: People's Press, 1997).

35. Jindai Zhongguo bainian guochi ditu, 25-26. 


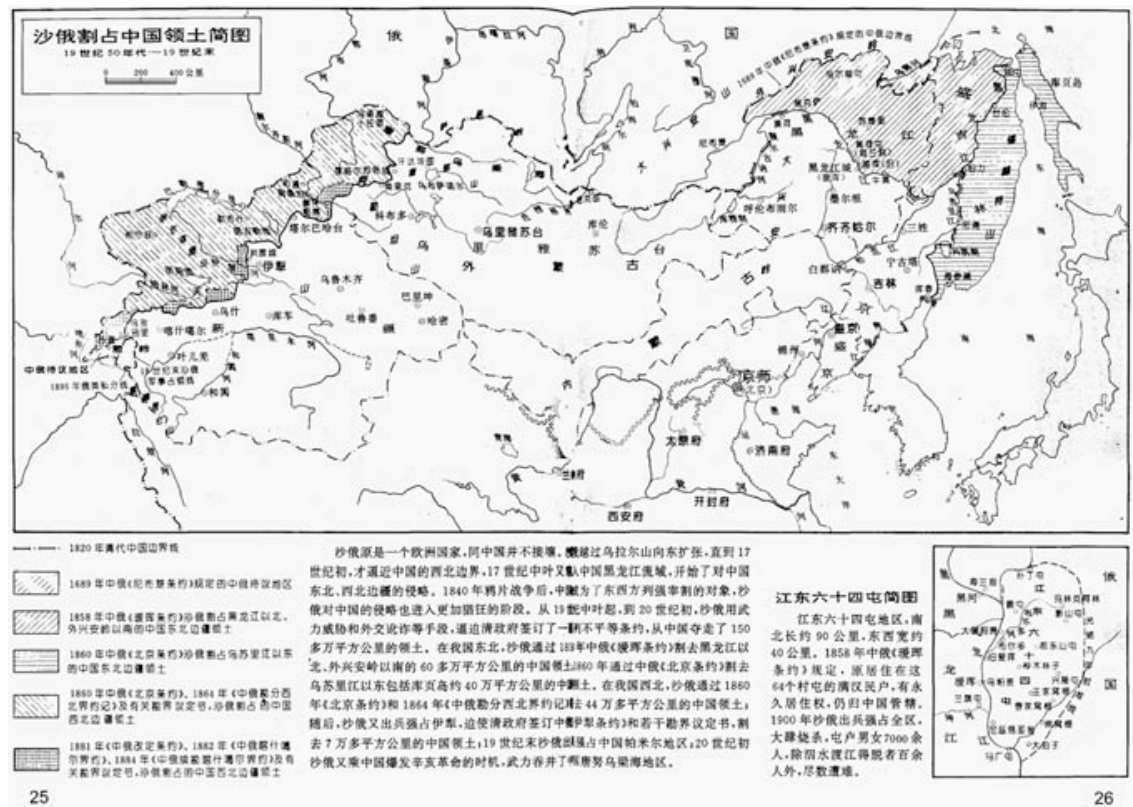

Figure 8 Czarist Russia's occupation of China's sovereign territory (1997). Jindai Zhongguo bainian guochi ditu, 25-26

This concern is manifest in the map "Imperialism's Division of China into Spheres of Power in the Late Nineteenth Century" (see fig. 9), which revives the turn-of-the-twentieth-century theme "carving up China like a melon and gobbling it up" for the turn of the twenty-first century. ${ }^{36}$ This resonates both with the map of the unraveling of China on the cover of China's Road (1999) analyzed above (see fig. 2) and with a famous 1898 Chinese cartoon of European, American, and Japanese empires dividing up China's territory (which is duly reproduced in the 1997 atlas). ${ }^{37}$ To drive home the continuing importance of the cartography of national humiliation in the twenty-first century, Maps of the Century of National Humiliation was republished in 2005, on higher-quality paper and with a sturdier binding, to mark the sixtieth anniversary of China's victory over Japan in World War II.

Like maps from the 1910s-1930s, post-1989 maps of national humiliation also combine the cartographies of imperial domain and sovereign territory to natural-

36. Jindai Zhongguo bainian guochi ditu, 47-48.

37. Jindai Zhongguo bainian guochi ditu, 49. 


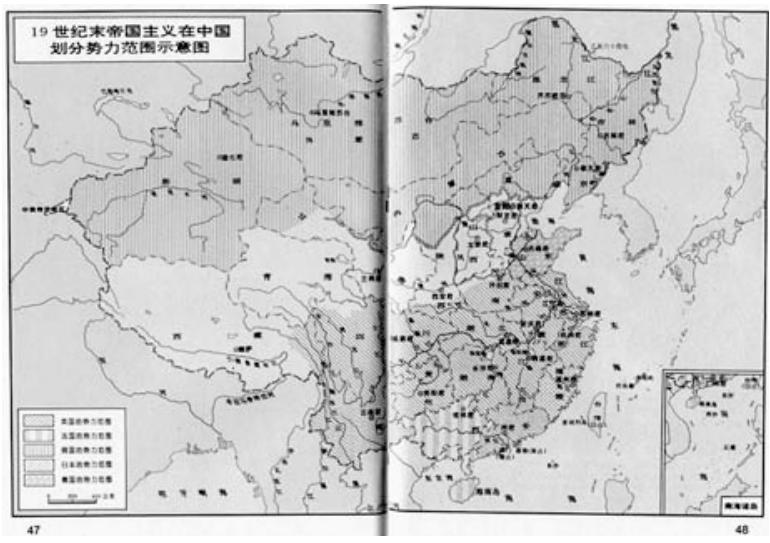

Figure 9 “Imperialism's

Division of China into

Spheres of Power in the Late Nineteenth Century" (1997). Jindai Zhongguo bainian guochi ditu, $47-48$

ize the borders of the PRC. Indeed, to claim unbounded frontiers as sovereign national territory, these national humiliation maps all employ the three discursive strategies outlined above. The maps very directly deploy the first strategy of denying the difference between imperial domain's hierarchical unbounded space and sovereign territory's homogeneous bounded space to craft China's modern geobody as a clearly defined national sovereign territory.

Following the second strategy of placing territorial changes in the context of the modern international politics of foreign imperialism, both early and recent maps frame the struggle as between China and the imperialist powers from Europe, America, and Japan that stole China's territories. This "Western imperialist" framework suppresses an alternative story: China, Russia, the West, and Japan were rival expansionists, fighting over the same territorial prey - the vassal states, semistates, and frontier zones on the periphery of the Qing imperial domain, such as Mongolia, Korea, Vietnam, and Siberia. ${ }^{38}$ Indeed, spaces marked as "lost territories" on twentieth-century maps were conventionally marked as "gained territories" on Qing dynasty's eighteenth-century maps. ${ }^{39}$

Generally, these national humiliation maps employ the Westphalian international system's grid to reduce, classify, or exclude the voices of these quasi states and allow only the story of the "great unity" of the emerging Chinese nation-state

38. See Peter C. Perdue, China Marches West: The Qing Conquest of Central Eurasia (Cambridge, Mass.: Harvard University Press, 2004).

39. Joanna Waley-Cohen, "Changing Spaces of Empire in Eighteenth-Century Qing China," in Political Frontiers, Ethnic Boundaries, and Human Geographies in Chinese History, ed. Nicola Di Cosmo and Don J. Wyatt (London: RoutledgeCurzon, 2003), 333. See also "Da Qing wannian yitong dili quantu." 
to be heard. This, then, is a prime example of the third discursive strategy: read territoriality exclusively from Beijing's point of view, thus suppressing any rival perspectives that would produce alternative geobodies.

The result of these cartographic strategies is paradoxical: rather than evidence of a loss of national territories along Siberian, Central Eurasian, Northeast Asian, and South Asian frontiers, these national humiliation maps show how China has asserted national sovereignty over an ambiguous imperial domain, transforming the periphery into an integrated sovereign territory that includes some, although not all, of the former Qing realm. National humiliation maps and impassioned discussions of "lost territories" therefore have actually helped China strengthen its claim to frontier zones in Xinjiang, Tibet, Manchuria - and Taiwan. Both dismembering and re-membering thus are key biopolitical strategies in the production of a geobody.

\section{Comparative Cartography 2: \\ National Maps and National Humiliation Maps}

While these maps of national humiliation are certainly interesting and raise serious questions about the proper size and shape of China, it is easy to dismiss them as the exception to the rule of China's standard practice of national sovereignty. Yet an examination of a wider selection of China's official and popular maps from the early twentieth century and the turn of the twenty-first century shows that these national humiliation maps are an integral part of the emergence of nationalist cartography in China. The same geographic societies and commercial presses that published national humiliation maps often simultaneously published "national maps" containing the same images and information. Figure 6's "Map of China's National Humiliation" is actually the second map in the Atlas of the Republic of China (1930) — the first map is simply labeled the "Republic of China." Moreover, most "normal" and official maps of the ROC contain important references to China's national humiliation: they characteristically mark "lost territories" and list unequal treaties, treaty ports, and territorial concessions. The "Latest Detailed Complete Map of the Republic of China" (1923) is literally framed by the cartography of national humiliation's now familiar inset maps, annotations, and charts. Its inset maps, for example, show the details of particular "lost territories," while the main map labels surrounding countries like Korea and Annam (Vietnam) as countries that used to be "our vassals" and now are Japan's or France's vassals. ${ }^{40}$

40. "Zuixin xiangxi Zhonghua minguo diyu quantu" ("The Latest Detailed Complete Map of the Republic of China") (n.p., 1923). 
As in the Geography of China's National Humiliation (1930), an impassioned statement is written along the bottom margin of the "Latest Detailed Complete Map," declaring that Chinese people can "cleanse their national humiliation" only by studying this map, which shows how their country's sacred territory was lost to Europeans and Japanese.

The "Patriotic Map: National Humiliation and National Assets in One View" (1929) shows how the cartography of national humiliation informs mainstream national maps in China in a different way. ${ }^{41}$ This fascinating map shows how recording and publicizing China's territorial humiliations has always been closely tied to patriotism, national pride, and campaigns for national salvation. Alongside annotations celebrating the strength of China's industry and infrastructure (Chinese-owned factories, mines, orchards, etc.) are red-dotted notes to treaty ports and "lost territories." Altogether, these cartographic strategies produce China's national geobody by linking imperial domain with sovereign territory.

The dual pattern of cartography at the turn of the twenty-first century is similar. Like those of the 1920s and 1930s, recent national humiliation maps are not only very similar to the standard maps found in the Atlas of Modern Chinese History (1984); the editors of Maps of the Century of National Humiliation (1997) credit this and other modern Chinese history atlases as their main sources. ${ }^{42}$ Although it does not use the phrase "national humiliation," the monumental and comprehensive History of China's Modern Borders (2007) uses the same hybrid logic to combine the cartographies of imperial domain and sovereign territory in the service of asserting China's "great unity"; it also employs the now familiar maps of China's ancient borders and czarist Russia's subsequent theft of Chinese territory. ${ }^{43}$ Recent national humiliation maps also overlap considerably with a patriotic education atlas produced by the party's central propaganda department: the Atlas of One Hundred Patriotic Education Sites (1999). ${ }^{44}$ These and other Chinese

41. I have studied the "Patriotic Map" at Beijing's National Library. Unfortunately, my request for a copy was denied because the map is very fragile.

42. Jindai Zhongguo bainian guochi ditu, 86; see also Zhang Haipeng, Zhongguo jindaishi gao dituji (Atlas of Modern Chinese History) (Shanghai: Cartographic Press, 1984).

43. Lü, Zhongguo jindai bianjie shi, 1:1-8, 264, 276, 324, 342, 352. This edited volume is the result of a major research project by the Center for the Study of Borderland History and Geography at the Chinese Academy of Social Sciences. According to a scholar at this center, the book was written to set the standard for border studies over the next few decades (anonymous historical geographer, interview by author, Beijing, July 17, 2007).

44. Zhao Ming, ed., Baige aiguo zhuyi jiaoyu shifan jidi dituji (Atlas of One Hundred Patriotic Education Sites) (Beijing: China Cartographic Press, 1999). 
maps thus show how the cartography of national humiliation is an integral part of official, scholarly, and popular imaginings of China's geobody.

These national humiliation maps are more than historical curiosities. They show how scientific cartography has paradoxically reenchanted China, producing a modern geobody that is at the same time a sacred national space.

\section{Border Diplomacy}

These national maps and national humiliation maps have shown how, starting with the Opium War in 1840 and continuing through the Republican revolution against the Qing dynasty in 1911, the Communist revolution in 1949, and economic reforms in 1978, China has experienced dramatic changes not only politically but also spatially. Modernity introduced not only contingent concepts to China but also contingent borderlands. Indeed, both the imperial era and the Cold War were characterized by border wars for China; from 1949 to the 1970s the PRC engaged in a series of border wars with almost every neighboring country, most famously with India (1962), Russia (1969), and Vietnam (1979). After the PRC fired missiles in the Taiwan straits confrontation (1995-96), many were again concerned about Chinese irredentism. ${ }^{45}$

Maps are a key part of such border disputes: after the Sino-Indian War (1962), Delhi complained about "Chinese aggression in maps," and in the 1990s Beijing's Southeast Asian neighbors worried about "cartographic aggression" after China published official maps that include a "historic claim line" that digs deeply into the South China Sea and is reminiscent of national humiliation maps. ${ }^{46}$

But Allen Carlson and M. Taylor Fravel have separately argued that a close analysis of border disputes shows that the PRC often prefers to negotiate solutions with its neighbors - even if this means giving up more than half of the disputed territory. ${ }^{47}$ Carlson explains that the PRC shifted from military coercion

45. M. Taylor Fravel, "Regime Insecurity and International Cooperation: Explaining China's Compromises in Territorial Disputes," International Security 30 (2005): 46; see also Maria Chang, "Chinese Irredentist Nationalism," in Return of the Dragon (Boulder, Colo.: Westview, 2001), $205-26$.

46. Old Secretariat, Chinese Aggression in Maps: Nine Maps, with an Introduction and Explanatory Notes (Delhi: Publications Division, 1962); the Southeast Asian concern is cited in Greg Austin, China's Ocean Frontier: International Law, Military Force, and National Development (Sydney: Allen and Unwin, 1998), 331.

47. See Allen Carlson, Unifying China, Integrating with the World: Securing Chinese Sovereignty in the Reform Era (Stanford, Calif.: Stanford University Press, 2005), 49-91, 231; and Fravel, "Regime Insecurity." 
to a policy of normalizing borders through diplomacy and international law as the economic reform policy took hold in the 1980s. This was part of Beijing's broader understanding that acting as a responsible member of international society would contribute to the peaceful international environment that is crucial for the success of China's domestic economic reform project. Fravel argues that the positive policy of negotiating boundaries began much earlier — in the early 1960s — and has less to do with economic reform policy than with China's national security problem of stabilizing ethnic politics along its frontiers. China compromised in border disputes when it faced internal threats to regime security from transnational ethnic groups that straddled international borders. The PRC thus often made territorial concessions to its neighbors in Central Eurasia in exchange for cooperation in stopping cross-border ethnic movements, which Beijing saw as "separatist movements." Whether because of economic reform policy or national security concerns, China has settled seventeen of its twenty-three border disputes and is dealing with the remaining disputes largely in a noncoercive spirit. ${ }^{48}$

Yet Carlson notes that alongside this cooperative diplomatic strategy there is a significant undercurrent among China's national security and foreign policy experts of "memories of the contraction of Chinese territory during the "century of humiliation." "49 The PRC's boundary disputes since 1949 thus are an imperial legacy that continues to be informed by much broader "historically grounded understandings of the 'legitimate' scope of China's territorial sovereignty." 50 Although the PRC has negotiated most of its disputed boundaries, yearnings to recover a vast collection of "lost territories" continue to emerge in official, semiofficial, and popular discourse.

Because it is located at the crossroads of various empires, Manchuria exemplifies the cartographic complexity of colliding geobodies. ${ }^{51}$ Indeed, the only regional map of national humiliation represents Manchuria as a lost territory after Japan's 1931 invasion.52 Manchuria's uneasy status thus provokes various forms of resistance both inside China and abroad. So, for example, soon after China and Russia signed an agreement in 2004 to settle the disputed sovereignty of islands

48. On China's territorial disputes from 1949 to 2005, see Fravel, "Regime Insecurity," 56-57, table 1 .

49. Carlson, Unifying China, 50.

50. Carlson, Unifying China, 65.

51. See Mark C. Elliott, "The Limits of Tartary: Manchuria in Imperial and National Geographies," Journal of Asian Studies 59 (2000): 603-46.

52. "BaoRi qiangzhan woguo dongbei guochi tu" ("The Map of National Humiliation: Japan's Violent Occupation of Our Country's Northeast") (Shanghai: n.p., ca. 1932). 
at the confluence of the Amur and Ussuri rivers, Beijing was harshly criticized on the China Daily's online forum for the treasonous act of ceding Chinese territory. This critique, which was traced to the Web site of the China Cartographic Press, posted several very detailed satellite photographs of the islands and the controversial boundary settlement. Not surprisingly, the Chinese government quickly removed these Web pages. ${ }^{53}$ Other critiques of the Sino-Russian border continue to percolate among China's netizens, including items on the PRC's premier search engine, Baidu, which renamed the Russian Far East "Outer Manchuria." This Web site marks Outer Manchuria as an area of lost territory on a national humiliation-style map, and the text explains that it has been China's sovereign territory "since ancient times" and was lost when it "was invaded and occupied by czarist Russia." 54 Moreover, Maps of China's National Humiliation from the early twentieth century are continually rediscovered and posted in chat rooms to provoke patriotic discussion of "lost territories" among China's youth: one participant declares that we "must recapture the homeland," while others argue over the status of Mongolia and Korea. 55 On the Russian side of the border, there are palpable fears that China's "Yellow Horde" plans to employ "demographic pressures" to reclaim the Russian Far East from the dwindling ethnic Russian population. ${ }^{56}$ The cartography of national humiliation thus continues to animate Chinese (and Russian) popular understandings of China's proper geobody and provokes scattered protests on the Web. While we cannot rely on Wikipedia-like sites for "objective truth," they do show how activist groups are governing the production and distribution of alternative knowledges about China's proper geobody.

53. Zhang Qingmin, "Global Challenges, Domestic Pressures, and the Making of China's Foreign Policy" (paper presented at the British Inter-university China Center launch conference, Oxford, June 2007), 12; e-mail correspondence with Zhang, July 29, 2007.

54. In Chinese the area is usually called Outer Northeast (wai dongbei) and in English, Outer Manchuria. But the Web site makes clear that both refer to the same lost territory (baike.baidu.com/ view/173829.htm [accessed March 10, 2008]). See also the Chinese Wikipedia site, which is even more detailed and has a colored map that marks "lost territories" in red (zh.wikipedia.org/wiki/ \%E5\%A4\%96\%E6\%9D\%B1\%E5\%8C\%97 [accessed March 10, 2008]).

55. See Zhonghua Bantu Wang (China Map Net), www.uc321.net/bbs/viewthread.php ?tid=3303\& extra=page\%3D1 (accessed March 10, 2008); and Taizhou Qingnian Luntan (Taizhou Youth Discussion Forum), www.tz94.com/bbs/read.php?tid=46943 (accessed March 10, 2008).

56. See John Garnaut, "Russia on Edge as China Grows," Sydney Morning Herald, June 9, 2008, business.smh.com.au/business/russia-on-edge-as-china-grows; Mikhail Alexseev, "The 'Yellow Peril' Revisited: The Impact of Chinese Migration in Primorskii Krai,” Program on New Approaches to Russian Security (PONARS), Policy Memo series, no. 94 (October 1999): 2-3; and Alexander Lukin, The Bear Watches the Dragon: Russia's Perceptions of China and the Evolution of RussianChinese Relations since the Eighteenth Century (London: Sharpe, 2002). 
The "Koguryo controversy," by comparison, is a prime example of how the cartography of national humiliation is framing more official academic and diplomatic understandings of the geobody. As it does with Russia, China has discursive disputes with South Korea over Manchurian territories. While China's imperial and national humiliation maps commonly mark Korea as a vassal state, South Korean elites look to ancient history to claim what we now call Manchuria as Korean territory. These two discourses, which had largely bypassed each other for decades, collided when both North Korea and the PRC applied to the United Nations Educational, Scientific, and Cultural Organization (UNESCO) to recognize tombs from the ancient Koguryo Kingdom (37 BC-AD 668) as world heritage sites. Popular opinion was inflamed on July 1, 2004, when UNESCO recognized tombs in both North Korea and China as Koguryo world heritage sites. This led to a serious diplomatic dispute: on August 5 Seoul sent a senior diplomat to Beijing to protest China's "ongoing distortion of the history of Koguryo," and later that month Beijing sent a vice foreign minister to Seoul to iron out a five-point reconciliation plan. ${ }^{57}$ Several years later the controversy continues to smolder, with newspaper articles and scholarly works regularly reigniting it. 58

On the Chinese side, the UNESCO application was part of the Northeast Asia Project launched in 2002 by the same group that published the standard-setting History of China's Modern Borders (2007): the Center for the Study of Borderland History and Geography, which is part of the official Chinese Academy of Social Sciences think tank. The project's research on the Koguryo Kingdom, whose territory straddles the current PRC-North Korean border, concluded that this Korean dynasty was a vassal state in China's empire. Koreans thus are refigured from an independent nation to one of China's many "ethnic minorities." The Chinese media refers to this kingdom as "China's Koguryo" (analogous to references to "China's Tibet"), and China's Foreign Ministry removed Koguryo from its Web page on Korean history. 59

57. Peter Hays Gries, "The Koguryo Controversy, National Identity, and Sino-Korean Relations Today," East Asia 22 (2005): 3; Austin Ramzy, "Rewriting History," Time, August 16, 2004, www .time.com/time/magazine/article/0,9171,501040823-682338,00.html.

58. See "China's Claims for Korean History Revealed," Chosun Ilbo, June 4, 2007, english .chosun.com/w21data/html/news/200706/200706040026.html.

59. Gries, "Koguryo Controversy," 3-4; Ramzy, "Rewriting History.” There are numerous Chinese publications on Koguryo from the Northeast Asia Project. For discussions on claims to the Koguryo Kingdom as a former vassal, see Ma Dazheng and Jin Xizheng, eds., Gaoguli Bohai lishi wenti yanjiu lunwenji (Essays on the History of Koguryo and Parhae) (Yanji, Jilin: Yanbian Daxue Chubanshe, 2004). 
On the Korean side, Koguryo is central to national identity: the name Korea comes from this ethnic Korean kingdom. Koguryo thus is a foundational site of Korea's ancient history, not only for cultural reasons: this dynasty is particularly famous for resisting imperial China. Although the world heritage site is in North Korea, the controversy became a matter of national humiliation for South Koreans; patriotic citizens were enjoined to once again resist the threat of Chinese aggression. As an editorialist in Seoul writes, "This Chinese attempt to include Goguryeo as part of the history of China should be criticized for what it really is: an example of China-centered great-power chauvinism."60 South Korea's National Assembly "called on China to cease its efforts to distort history," and the prime minister was pressured to set up the Foundation for the Study of Goguryeo as a

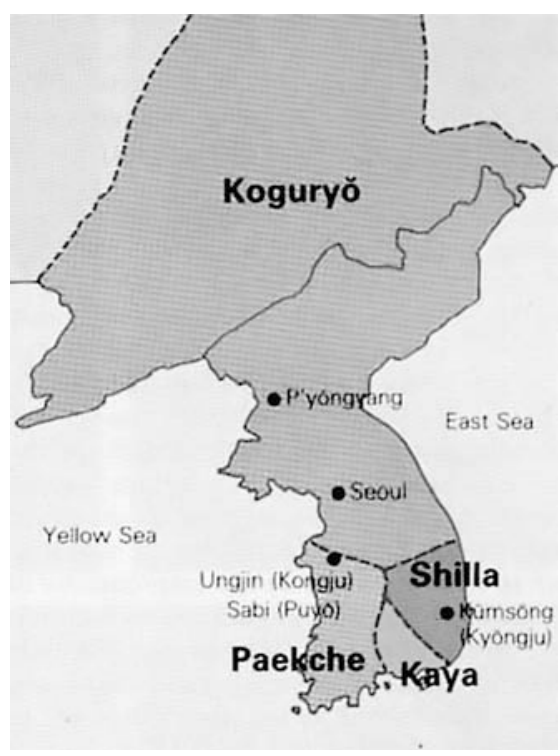

Figure 10 Koguryo Kingdom. "Goguryeo Kingdom" Web site, kokuryo.com direct response to China's Northeast Asia Project.61 While Chinese scholars look to imperial and national humiliation maps that list Korea as a vassal, Korea's scholar-activists not only look to ancient maps to argue their case, but many have now drawn their own expansive maps of the Koguryo Kingdom and posted them on the Web (see fig. 10). ${ }^{62}$

Northeast Asia's early history thus is the focus of heated debates over the nontraditional security issues of national identity. But these historical issues frame the very traditional security issue of the proper international border between Korea and China. Indeed, strategists on both sides agree that the Koguryo controversy is less about correctly recording "historical facts" than about the strategic intentions of the PRC and Korea in the twenty-first century. While some South Koreans worry about Beijing's plans to dominate Northeast Asia, many strategists in Beijing see the Northeast Asia Project as "preempting" any territorial claims that a reunified Korea would make on Manchurian territories, where the PRC's nearly 2 million ethnic Koreans live. ${ }^{63}$

60. Park Woo-Jung, “'Goguryeo, China,' and 'Dokdo, Japan'?” Hankyoreh, January 12, 2004, translated in Korea Focus, January-February 2004.

61. Park Young-sun, "China's 'Northeast Asia Project': Launch of a 'History War'?" Korean Historical Review, translated in Korea Focus, September-October 2004.

62. "Map Hints Chinese Territory as Ancient Korean," Korea Times, November 21, 2007; "Goguryeo Kingdom (BC 37-AD 668)," kokuryo.com (accessed March 10, 2008).

63. Anonymous international relations specialist, interview by author, Beijing, July 13, 2007; Gries, "Koguryo Controversy," 5-6; Park, "China’s 'Northeast Asia Project.", 
Thus, although the Northeast Asia Project and the Foundation for the Study of Goguryeo are on opposite sides of the Koguryo controversy, China and South Korea are both employing the strategies of the cartography of national humiliation. And Korea is not alone in using China's cartographic strategies to claim territory. While scholar-activists in South Korea argue that much of Manchuria is actually Korean, Thailand likewise has a history of seeking to claim its former vassals in Laos, Cambodia, Assam, Burma, and Yunnan as integral parts of a sovereign pan-Thai geobody. ${ }^{64}$ Hence South Korea and Thailand use a similar dual cartographic logic in their own narratives of "lost territories" to inspire normative and aspirational geobodies that encroach on China's own national map.

While China's diplomats are busy negotiating solutions to international border disputes, alternative voices continue to emerge both in China and abroad. This is evidence of the effectiveness of maps for patriotic education in China and other countries: these nativists all continue to crave the return of what they see as "lost territories." In a way, the cartography of national humiliation is too persuasive; the biopolitics of this geobody actually exceeds Beijing's diplomatic strategy that seeks to map China as part of the world.

\section{Alternative Geobodies}

Resistance to China's expansive geobody also emerges on the domestic front in the frontier areas of Xinjiang, Hong Kong, and Taiwan. Artisans in Northwest China, for example, have woven the PRC out of a carpet to highlight Xinjiang as its own entity (see fig. 11). ${ }^{65}$ The carpet plays with the tension between two conflicting geobodies. On the one hand, the carpet's meaning is very official, because the design is based on a road map of the Xinjiang Uyghur Autonomous Region found in any Chinese atlas. On the other hand, the carpet subversively portrays Xinjiang as separate from China, because the design obscures the difference between internal provincial boundaries and external international boundaries. This carpet thus uses the cartography of sovereign territory to assert the geobody of Xinjiang; it does not contest the logic of borders so much as reframe them from internal boundaries to external boundaries.

64. See, e.g., How Thailand Lost Her Territories to France (Bangkok: Department of Publicity, 1940). The maps in this official book come from World War II, when imperial France could not protect its Indochinese colonies, which were occupied by Japan and Thailand. Bangkok was forced to return its newly recovered territories after the war. But such views of expansive Thai space continue to inspire unofficial pan-Thai movements in the twenty-first century.

65. The photograph of the carpet was taken by Ablimit Baki at a weaving collective in Hotan, 2005. 


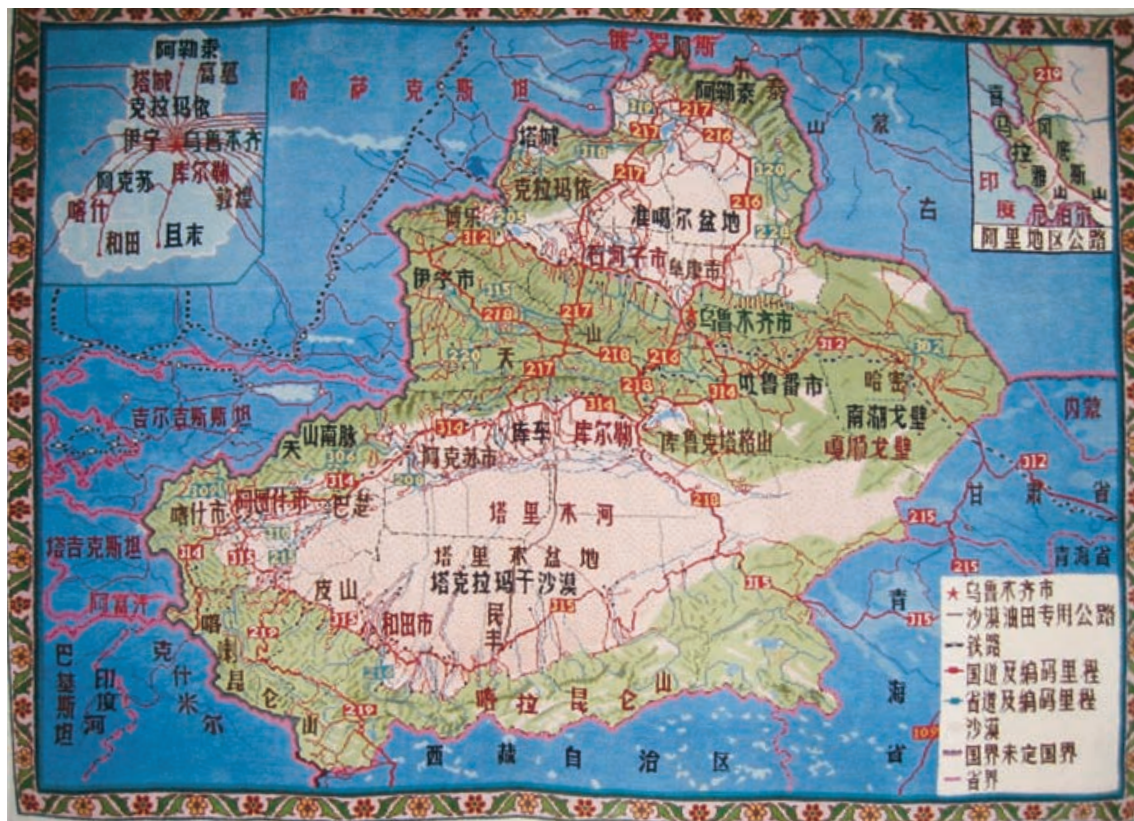

Figure 11 Carpet map (2005). Courtesy of Ablimit Baki

Resistance in Hong Kong and Taiwan, however, calls into question the cartographic conventions taken for granted on this Xinjiang carpet map. Rather than argue over the correct borders of sovereign territory, in The Atlas: An Archaeology of an Imaginary City the Hong Kong novelist Dung Kai Cheung discusses the return of Hong Kong as a conceptual issue. While Maps of China's National Humiliation (1997) stresses the geopolitical and legal aspects of how Britain's gunboat diplomacy and unequal treaties stole Chinese territory, the Atlas treats the territorial border as a site of aesthetic performances. Thus Dung does not resist British or Chinese sovereignty in the expected way of asserting Hong Kong as an independent sovereign territory. Rather, he takes a conceptual-and frankly satirical - approach to understand Hong Kong's contingent historical and geographic position. The Atlas thus makes sense of Hong Kong's messy history at the intersection of two empires by deploying a set of eccentric cartographic concepts: counterplace, commonplace, misplace, displace, antiplace, nonplace, extraterritoriality, boundary, utopia, supertopia, subtopia, transtopia, multitopia, unitopia, and omnitopia. Dung's complex approach to cartography thus shifts from the conventions of a two-dimensional map to create an overlapping and multiple space 
that undermines the hegemonic understanding of the modern notion of territorial sovereignty. ${ }^{66}$ The Atlas therefore is quite good at capturing Hong Kong's transnational dynamic, which is difficult to represent on standard maps. Indeed, as in Susan Sontag's On Photography, one of Dung's tactics for resisting the discourse of territorial sovereignty is to refuse to display any maps at all.

While the carpet cartograph uses a standard map to resist the PRC, and Dung theorizes against maps to locate Hong Kong in transnational space, resistance in Taiwan employs both mathematical maps and critical cartography to contest Chinese hegemony. During the Cold War, maps of the ROC (whose government fled to Taiwan with the founding of the PRC in 1949) reflected the ROC's political aspirations to reconquer the mainland - and Mongolia too. Yet with the rise of Taiwan's independence movement, which seeks to separate the island from Chinese sovereignty, new maps have appeared to sketch out a new autonomous geobody. In addition to simply drawing Taiwan island as an entity separate from the mainland, at times Taiwan's maps have resisted the conventions of modern Chinese cartography to assert their own perspective. Following the hegemonic cartographic practice of the Mercator projection, official maps in Asian put the North on top and the West on the left, thus generally valuing the North over the South and the West over the East. ${ }^{67}$ On China's national maps, Taiwan is located in the worst symbolic quadrant: the Southeast.

In 2004 Taiwan's secretary of education unveiled a new "Series of Maps from Taiwan's Perspective" for use in the island's middle schools, including the "Change the Perspective to View Taiwan" map (see fig. 12).68 This fascinating map very deliberately challenges cartographic conventions to put Taiwan at the center of the map as an independent maritime nation rather than as a peripheral province of a continental power. As its notes tell middle school students:

Perhaps this map is confusing to people because it shifts from the normal situation where the North is up and South is down to one where the Southeast is up and the Northwest is down. This map enables us to see our neighbors more clearly, from Japan on the left to the Philippines and Indonesia on the right. These East Asian countries are not only our neighbors; in terms of their geological environment, they are Taiwan's brothers.

66. Dung Kai Cheung (Dong Qizhang), Dituji: Yige xiangxiangde chengshide kaoguxue (The Atlas: The Archaeology of an Imaginary City) (Taibei: Lianhe Wenxue, 1997).

67. For an analysis of cartography's ethical hierarchy that values the upper left over the lower right, see Mignolo, Darker Side, 259.

68. "Huan ge jiaodu kan Taiwan" ("Change the Perspective to View Taiwan"), comp. Geography Department, National Taiwan University (Taibei: Council for Cultural Affairs, 2004). 


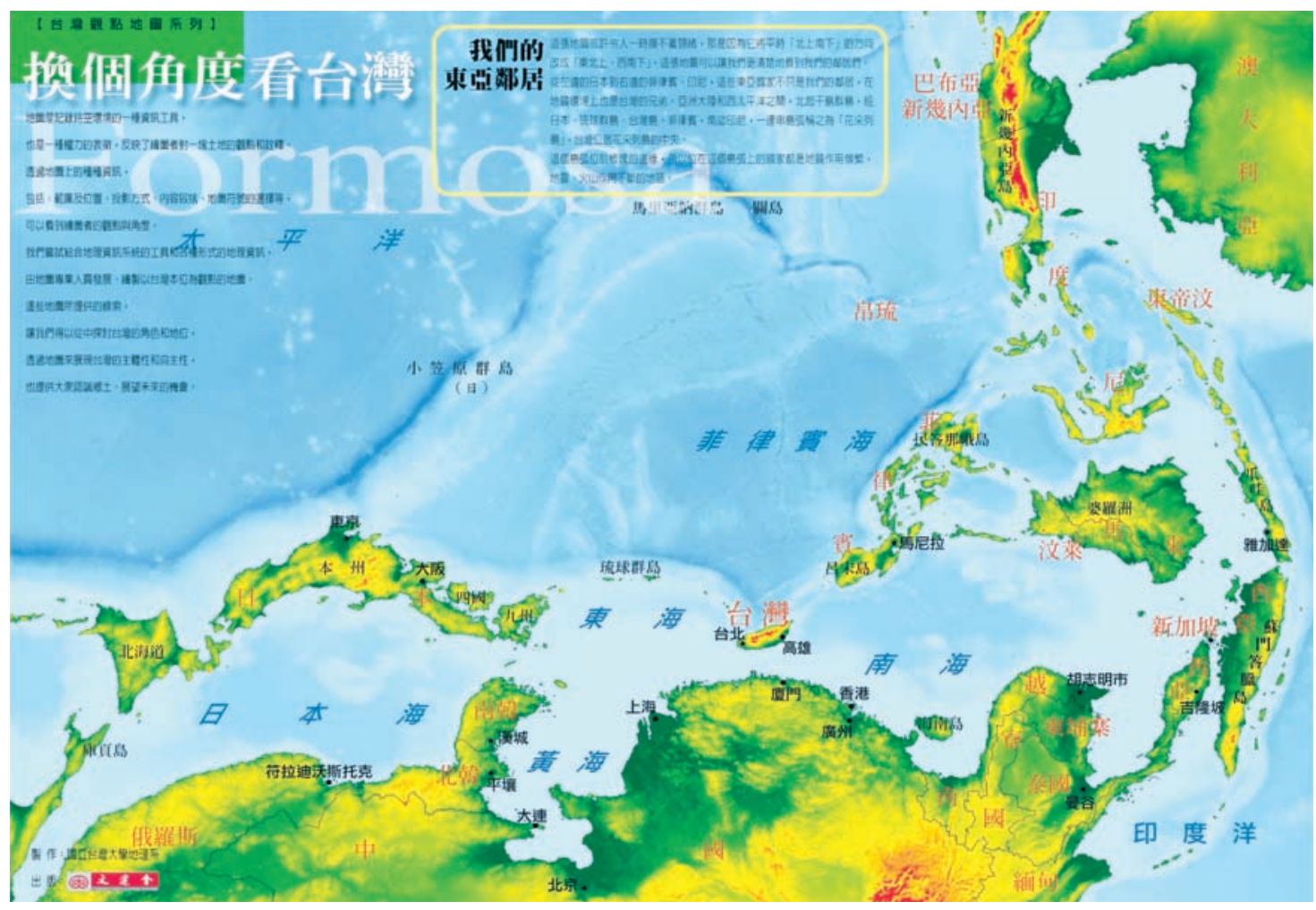

Figure 12 "Change the Perspective to View Taiwan" (2004). Council for Cultural Affairs, Taiwan
Many proponents of Taiwan's reunification with China were outraged by what they saw as a "politicization" of Taiwan's map. But what is most interesting about the "Change the Perspective to View Taiwan" map is how this strange image highlights how we have to work very hard to interpret not only this map but any map. The purpose of this map thus is not only to represent Taiwan; its notes instruct us that its goal is to "critically interrogate cartography's system of tools," which includes determining the map's "scope and position, the way it is projected, how its content is selected, the choice of map symbols, and so on."

While national humiliation maps fudge the contradictions between imperial domain and sovereign territory and thus obscure their own relations of production, the perspectival map of Taiwan is much more honest about how it uses conventions to create political meaning. While the national humiliation maps' annotations of "lost territories" (which we are told have been Chinese "since ancient times") tend to naturalize ambiguous space as national territory, the annotations on the "Change the Perspective to View Taiwan" map underline how it is created 
by and for a particular Taiwanese point of view; that is why it is so controversialand so successful.

As in Xinjiang and Hong Kong, people in Taiwan creatively employ cartographic strategies to challenge China's simple conversion of imperial domain into national territory. In particular, these three alternative geobodies resist the last discursive strategy of drawing maps exclusively from Beijing's point of view.

These last two sections on border diplomacy and alternative geobodies underline the biopolitical nature of the cartography of national humiliation. They show how the overlap is not only between imperial domain and sovereign territory; managing sovereign territory also is intertwined with managing ethnic(ized) populations both on the periphery and at the center.

\section{Conclusion: Geopolitics and Biopolitics in Creative Tension}

While we assume that we can easily locate "China" on the map, these fascinating and perplexing maps show that the debate over where China begins and ends is ongoing, especially in domestic discussions among Chinese intellectuals. These maps graphically show that the transition from imperial Chinese cosmology to modern scientific geography has not been complete. Indeed, China's geobody actually emerges from the interplay of the otherwise contradictory cartographic conventions of imperial domain space and sovereign territory space. Yet after a century of crafting, China's geobody is still neither stable nor hegemonic; it faces counterdiscursive resistance on many fronts.

The Chinese-language materials examined here rarely emerge in Westernlanguage analysis of China. Although it is not necessarily the dominant view, it is necessary to understand how the cartography of national humiliation still animates official, scholarly, and popular understandings of national territoriality in China. Most important, these maps show a strangely anxious popular countercurrent to Beijing's current positive images of the PRC as a "peacefully rising" power.

But this is not to say that China has irredentist geopolitical ambitions for the twenty-first century. The goal of national humiliation maps is no longer primarily to recover lost territory; it is to cleanse the stains of lost honor and pride. The desire is not so much for material territory as for symbolic recognition, acceptance, and respect. The challenges that China faces thus are more biopolitical than just geopolitical; rather than emanate from some grand "Western conspiracy" (see fig. 2), these challenges arise in China's own backyard through its symbolic and cartographic relations with Russia, South Korea, Thailand, Vietnam, the new 
Central Asian states, and Taiwan. If anything, these maps suggest that, rather than look abroad for more territory, Beijing is most concerned with the biopolitical challenges posed by ethnic minority groups like Tibetans that occupy borderlands already inside China's sovereign territory.

The cartography of national humiliation is uniquely prominent in China, yet the biopolitical struggles of its national geobody resonate beyond its borders. On the one hand, activists in other countries are also crafting aspirational geobodies to reclaim "lost territories": Ireland, Israel, Mexico, and so on. On the other hand, some transnational groups are imagining normative geobodies as a way to get onto the current geopolitical map: Kurds, Basques, and so on. These alternative geobodies not only imagine new territorial boundaries but also manage the hopes and fears of populations. Hence, while many are declaring a grand shift from geopolitics to biopolitics, the cartography of national humiliation shows how geopolitics and biopolitics are intertwined in a creative tension that promotes the management of territorial borders as it regulates the flow of populations.

Hence national humiliation maps (like all maps) tell us not simply where we are but also how to feel. In this way, national maps are part of the broader discourse of national security, which generally tells us less about the geopolitics of defending territorial boundaries than about the biopolitics of "tell[ing] us who we must be." 69 And where we must be.

\section{Cartobibliography}

1418 map. www.1421.tv/assets/images/maps/1418_map_download.jpg.

Aiguo ditu: Guochi yu guochan yilan (Patriotic map: National humiliation and national assets in one view). Meeting of the Central Government, Wuhan Branch meeting, 1929. National Library of China.

BaoRi qiangzhan woguo dongbei guochi tu (The map of national humiliation: Japan's violent occupation of our country's Northeast). Shanghai: n.p., ca. 1932. Daniel K. E. Ching Collection, Hoover Institution Archives, map case 93021.

Da Qing wannian yitong dili quantu (Complete universal map of the unified Great Qing empire). 1816. Library of Congress, hdl.loc.gov/loc.gmd/g7820 .ct002256.

69. R. B. J. Walker, "The Subject of Security,” in Critical Security Studies, ed. Keith Krause and Michael C. Williams (Minneapolis: University of Minnesota Press, 1997), 71-72. 
Huan ge jiaodu kan Taiwan (Change the perspective to view Taiwan), compiled by Geography Department, National Taiwan University. Taibei: Council for Cultural Affairs, 2004.

Huayi tu (Map of civilization and barbarism). 1136. Library of Congress.

Untitled map. 1743. British Library.

Zhongguo guochi ditu, zaiban (Map of China's national humiliation, reprint). Shanghai: Zhonghua Shuju, 1927. Chinese University of Hong Kong.

Zhongguo jianming guochi yutu (Simple map of China's national humiliation). Jiangsu Army Surveying Department, 1928. National Library of China.

Zhonghua guochi ditu (Map of Chinese national humiliation). Shanghai: Central Cartographic Society, 1916. Cornell University.

Zhonghua guochi ditu (Map of Chinese national humiliation). Henan Provincial Government, 1922. National Library of China.

Zhonghua guochi ditu (Map of Chinese national humiliation). Industry and Commerce Association of Hebei Province, 1929. National Library of China, Library of Congress.

Zhonghua guochi ditu (Map of Chinese national humiliation). Wuchang: Yaxin Geographical Society, 1931. National Library of China, Academia Sinica, Library of Congress.

Zuixin xiangxi Zhonghua minguo diyu quantu (The latest detailed complete map of the Republic of China). N.p., 1923. Harvard-Pussey Library. 
